\title{
PENGEMBANGAN MEDIA PROMOSI PARIWISATA KOTA TANGERANG DALAM BENTUK VIDEO DIGITAL PADA DINAS PORPAREKRAF
}

\author{
Giandari Maulani ${ }^{1}$ \\ Noviar Jalu Sasongko ${ }^{2}$ \\ Ardi Mulyana ${ }^{3}$

\begin{abstract}
Dosen Sistem Informasi STMIK Raharja ${ }^{1}$,Mahasiswa Teknik Informatika ${ }^{2}$, Mahasiswa Teknik Informatika ${ }^{3}$ Jl. Jendral Sudirman No. 40, Modernland, Tangerang

email: giandari@raharja.info, noviarjalu@ raharja.info, ardi@ raharja.info
\end{abstract}

\begin{abstract}
ABSTRAK
Perkembangan komunikasi, informasi dan promosi saat ini sangat berperan penting untuk masyarakat luas. Hal ini dibuktikan banyaknya suatu instansi atau perusahaan yang menyajikan komunikasi, informasi dan promosi, baik televisi, radio, internet maupun telepon. Saat ini Dinas Porparekraf, memberikan informasi dan promosi berupa video pariwisata melalui beberapa media yaitu berupa media sosial, maupun website yang dirasa masih belum cukup untuk memenuhi kebutuhan promosi pariwisata yang dirasa kurang up to date. Dinas Porparekraf harus memiliki sarana media informasi dan promosi yang dapat menunjang kemajuan pariwisata kota tangerang. Karena Kota Tangerang mempunyai banyak potensi pariwisata yang cukup menarik untuk dikunjungin masyarakat, jika potensi tersebut dapat dikelola dengan baik dan benar. Disamping itu, pola promosi yang up to date dan menarik takluput menjadi masalah untuk kekurangan pada Video promosi sebelumnya. Adapun metodelogi yang digunakan untuk melakukan penelitian ini, antara lain metode analisa permasalahan, pengumpulan data, analisa perancangan dan konsep produksi MAVIB (KPM) yaitu : Pre Production, Production dan Post Production. Demikian pada penelitian jurnal ini bertujuan untuk membuat media informasi yang berupa video pariwisata yaitu Pengembangan Media Promosi Pariwisata Kota Tangerang Dalam Bentuk Video Digital Pada Dinas Porparekraf, sehingga melalui pengembangan media tersebut sangat diharapkan dapat memberikan bentuk informasi pariwisata yang lebih menarik, up to date dan mudah diterima oleh masyarakat Kota Tangerang dan juga wisatawan.
\end{abstract}

Kata kunci : Pariwisata, Promosi, Video Digital.

\begin{abstract}
The development of communications, information and promotions at this time is very important to the wider community. This is evidenced by the large number of an agency or company that serves the communications, information and promotion, television, radio, internet or telephone. Current Porparekraf Service, providing information and promotion in the form of a video tourism through some media i.e. in the form of social media, as well as the website where it is still not enough to meet the needs of tourism promotion where less up to date. Porparekraf service must have the means of information and the promotion of media which can support the advancement of tourism city of tangerang. Because the city of Tangerang has a lot of tourism potential that is interesting enough to dikunjungin the community, if the potential can be managed with good and true. In addition, the pattern of
\end{abstract} Vol.2 No.2 - Agustus 2016 
the promotion is up to date and interesting takluput be a problem to a shortage on the previous promotional videos. As we used to do this research, among other issues, the analysis methods of data collection, analysis of the design and concept of the production MAVIB (KPM) i.e. Pre Production, Production and Post Production. So on research this journal aims to make media information in the form of video Media development namely tourism Promotion Tourism city of Tangerang in the form of Digital Video on the Porparekraf Service, so that through the development of the media are expected to give the shape a more attractive tourism information, up to date and easily accepted by people in Tangerang city and visitors alike.

Keywords : Tourism, Promotion, Digital Video.

\section{PENDAHULUAN}

Banyak perusahaan atau instansi menggunakan media video digital saat ini sebagai sarana informasi dan promosi. Video digital merupakan yang lengkap, karena video mempunyai unsur visualisasi yang nyata, gerak, suara, gambar dan banyak unsur musik dalam satu unit atau yang disebut dengan multimedia.

Pengembangan merupakan proses peningkatan keterampilan teoritis, teknis, moral dan konsepsual melalui penelitian dan pendidikan. Penelitian dan pendidikan yang diberikan agar sesuai dengan kebutuhan saat ini ataupun masa depan.

Video digital adalah serangkaian gambar digital yang menampilkan gambar secara cepat pada kecepatan yang konstan. Dalam ruang lingkup video, gambar ini biasa disebut dengan frame.

Dinas Porparekraf (Pemuda, Olahraga dan Ekonomi Kreatif) merupakan salah satu dinas terkait yang memiliki tanggung jawab untuk mempromosikan segala aset wisata yang ada di Kota Tangerang. Dinas tersebut beralamatkan di Jl. KS. Tubun No. 1 Gedung Cisadane Lt. 2 Kota Tangerang. Saat ini Dinas Porparekraf dipimpin oleh kepala Dinas dan terdapat satu sekretariat dan tiga bidang, yaitu : Bidang Kepemudaan, Bidang Olah Raga dan Bidang Pariwisata dan Ekonomi Kreatif. Untuk saat ini media informasi dan promosi yang terdapat pada Dinas Porparekraf masih berupa media yang kurang up to date terbukti dengan banyaknya pariwisata yang baru di bangun oleh Pemerintah Kota Tangerang.

Dari analisa kebutuhan yang dilakukan oleh penulis terhadap Dinas Porparekraf, dapat disimpulkan bahwa Dinas Porparekraf membutuhkan media yang lebih up to date dan menarik untuk dipromosikan kepada masyarakat Kota tangerang dan wisatawan.

\section{PERMASALAHAN}

Saat ini Dinas Porparekraf berkelanjutan mempromosikan sektor pariwisata yang ada di Kota Tangerang sebagai upaya meningkatkan kesejahteraan warga Kota Tangerang dan meningkatkan peran Kota Tangerang dalam konsentrasi destinasi pariwisata nasional. Seiring berkembangnya informasi mengenai sektor pariwisata yang ada di Kota Tangerang, Dinas Porparekraf dituntut untuk mengembangkan Video Pariwisata yang baru dengan informasi yang up to date sesuai dengan perkembangan Kota Tangerang untuk saat ini. Melalui pengembangan video pariwisata diharapkan masyarakat atau wisatawan lebih mengenal sektor pariwisata yang ada di Kota Tangerang, selain itu juga pemerintah berharap agar wisatawan luar dan investor berdatangan ke Kota Tangerang. 
Berdasarkan hasil pengamatan yang telah dilakukan, maka dapat dirumuskan beberapa Permasalahan yang ada pada Dinas Porparekraf Kota Tangerang yakni, sebagai berikut :

1. Bagaimana menyajikan sebuah video pariwisata Kota Tangerang yang informatif serta dapat menjadi media promosi untuk Kota Tangerang?

2. Bagaimana membuat media audio visual yang terkonsep menarik dan dapat memenuhi kebutuhan promosi daerah Kota Tangerang?

3. Target seperti apa yang dicapai melalui pengembangan video promosi pariwisata Kota Tangerang?

\section{LITERATUR REVIEW}

Dalam upaya mengembangkan dan menyempurnakan penelitian jurnal ini perlu dilakukan studi pustaka (literature review) sebagai salah satu penerapan metode penelitian yang akan dilakukan sebagai bahan perbandingan. Diantaranya yaitu:

1. Penelitian yang telah dilakukan oleh Yasa Sidik Permana $(2012)^{[11]}$,dengan judul

"Perancangan Dan Pembuatan Video Promosi Wisata Alam Dan Edukasi Lingkungan Dolandeso Boro Daerah Banjar Asri Kabupaten Kulon Progo". Pendidikan lingkungan dan alam atraksi wisata Dolan deso Boro adalah tempat wisata dengan berbagai kegiatan budaya untuk pendidikan lingkungan yang rekreasi pendidikan. Promosi wisata alam dan pendidikan lingkungan Dolan deso Boro dilakukan dengan mendekati konsumen dengan presentasi. Berdasarkan studi pendahuluan kegiatan promosi pariwisata alam dan pendidikan lingkungan Dolan deso Boro masih memiliki beberapa masalah energi boros (Karena konsumen pemasaran Dolan deso harus pergi satu per satu dan menyajikan secara manual), tidak praktis (karena promosi tidak dapat dilakukan secara bersamaan, dan yang spread lambat), tidak selalu tepat sasaran (kesulitan manual disajikan kepada sekolah / Perguruan tinggi / standar perusahaan / organisasi karena belum tentu langsung ditargetkan pada konsumen mempresentasi / media biasanya melalui perantara), kurangnya kepercayaan konsumen (seperti dalam promosi manual masih kurang bukti Objek wisata yang dipromosikan).

2. Penelitian yang dilakukan Tyas Ajeng Nastiti,dkk (2013) $)^{[9]}$, yang berjudul "Perancangan Video Promosi Surabaya Berupa Tvc Sebagai Media Promosi Kota Surabaya Dengan Mengangkat Pencitraan Sparkling Surabaya". Pamor kota Surabaya sebagai kota terbesar kedua setelah Jakarta di mata Wisatawan Nusantara (wisnu) masih kurang memadai. Hal ini terlihat dari rendahnya minat wisatawan berkunjung ke daerah wisata di kota Surabaya. Sejak 2006, Surabaya memiliki identitas Sparkling Surabaya. Setidaknya terdapat 5(lima) keunggulan potensi wisata kota Surabaya. Dibutuhkan sebuah media modern yang mampu mendongkrak promosi kota Surabaya. Berbagai media promosi yang dirancang masih sebatas media konvensional seperti brosur, peta, dan lain sebagainya. Oleh karena itu, dibutuhkan sebuah media moderen yang mampu mendongkrak promosi kota Surabaya. Video promosi menjadi salah satu media efektif dalam mempromosikan identitas Sparking Surabaya. Dengan konsep yang moderen dan semangat jiwa muda, video promosi kota Surabaya diharapkan mampu menarik minat wisnu bahkan wisatawan mancanegara (wisman) untuk mengunjungi berbagai wilayah wisata di kota Surabaya. 
3. Penelitian yang dilakukan Mirzza Al Akbarian,dkk (2012) ${ }^{[1]}$, penelitian ini membahas tentang "Perancangan Video Promosi Wisata Jawa Timur". Pariwisata mempunyai peranan yang sangat besar dalam pengembangan perekonomian begitu juga di Indonesia. Jawa Timur yang merupakan salah satu propinsi di Indonesia dengan segala potensinya memiliki kekayaan alam dan budaya yang sangat beragam. Dengan potensinya yang cukup besar Jawa Timur layak untuk mendapat apresiasi lebih dari wisatawan khususnya wisatawan mancanegara oleh karena itu dibutuhkan berbagai media promosi yang dapat mempersuasi wisatawan untuk datang ke Jawa Timur. Video merupakan salah satu media yang mempunyai banyak kelebihan dan dapat menjadi media pelengkap media lain yang dikeluarkan oleh Dinas membidangi kepariwisataan di Jawa Timur. Petualangan merasakan keragaman yang ada di Jawa Timur merupakan hal yang akan disampaikan dalam video promosi wisata Jawa Timur.

4. Penelitian yang dilakukan Setyowati, dkk (2012) ${ }^{[14]}$, berjudul "Perancangan Video Sebagai Sarana Promosi Daya Tarik Wisata Kabupaten Pasuruan". Daya tarik wisata adalah segala sesuatu yang mengandung unsur keunikan, keindahan dan nilai yang berupa keanekaragaman kekayaan alam, budaya dan hasil buatan manusia yang menjadi sasaran atau tujuan kunjungan wisatawan. Pariwisata telah menjadi industri yang mendunia, suatu bisnis yang semakin berkembang. Kabupaten Pasuruan memiliki wisata yang potensial, tetapi banyak masyarakat yang tidak mengetahui. Oleh karena itu, video tentang daya tarik wisata Kabupaten Pasuruan diharapkan menjadi sarana promosi yang efektif. Model perancangan video ini mengembangkan dari model perancangan prosedural dengan pendekatan penelitian kualitatif melalui pengumpulan data dari latar alami dengan memanfaatkan diri peneliti sebagai instrumen kunci. Langkah-langkah perancangan harus membentuk aliran yang harus diikuti, mulai dari latar belakang masalah sampai desain final. Desain final harus dapat menjawab latar belakang masalah dan rumusan masalah, sehingga aliran itu seolah-olah kembali ke latar belakang masalah perancangan yang dinyatakan dengan garis putus-putus. Hasil perancangan ini berupa video yang memberikan informasi serta digunakan sebagai promosi daya tarik wisata Kabupaten Pasuruan.

5. Penelitian yang dilakukan oleh Ahmad Santoso (2015) ${ }^{[12]}$, membahas tentang "Perancangan Video Promosi Infografis Destinasi Wisata Kota Surakarta". Pengantar karya Tugas Akhir ini berjudul "Perancangan Video Promosi Berupa Infografis Destinasi Wisata Kota Surakarta". adapun permasalahan yang dikaji adalah : Bagaimana merancang video promosi berupa infografis destinasi wisata Kota Surakarta yang menarik dan informatif secara konsep visual? Media pendukung apa saja yang efektif dan relevan untuk mendukung video promosi destinasi wisata Kota Surakarta? Surakarta atau yang biasa disebut Solo merupakan kota yang memiliki beragam tujuan wisata seperti, wisata sejarah, wisata seni dan budaya, wisata religi, wisata belanja dan wisata kuliner. Dengan banyaknya tujuan wisata maka diperlukan sebuah media promosi yang dapat mencakup keseluruhan informasi mengenai tujuan wisata tersebut. Video promosi merupakan salah satu bentuk media promosi yang dapat mencakup keseluruhan informasi yang ingin disampaikan. Untuk saat ini video promosi untuk mempromosikan pariwisata kota Surakarta sudah ada, namun masih berupa live shot dan dirasa sudah tidak representatif lagi untuk dijadikan media promosi wisata Surakarta. Maka dari itu diperlukan sebuah terobosan baru untuk mempromosikan tujuan wisata kota Surakarta melalui video promosi dengan cara yang berbeda. Video infografis

Vol.2 No.2 - Agustus 2016 
merupakan jawaban yang menjanjikan karena disamping masih jarang digunakan di Indonesia untuk mempromosikan tempat wisata, video infografis juga memiliki keunikan tersendiri untuk menyampaikan sebuah informasi dalam bentuk audiovisual. Dengan asumsi di atas, penulis terdorong untuk mempromosikan destinasi wisata kota Surakarta melalui video promosi berupa infografis.

6. Penelitian yang dilakukan oleh Siti Sofri Ayu Cristianti $(2015)^{[2]}$, dengan judul "Video Promosi Rockradio live.co". Adapun Rockradiolive.co merupakan salah satu radio streaming yang berada di Jakarta, tepatnya berada di daerah Kemang, Jakarta Selatan. Rockradiolive.co memberikan wadah untuk para komunitas-komunitas pecinta musik rock untuk menyalurkan bakat mereka. Dengan menyalurkan bakat musik yang mereka miliki, Rockradiolive.co menyediakan ruang seluas-luasnya untuk para pecinta musik rock yang berada di Indonesia khususnya di Jabodetabek. Saat ini media promosi dan juga kampanye yang mengajak masyarakat untuk menunjukkan bakat musik mereka sudah sangat minim. Oleh sebab itu, tugas akhir ini akan merancang pembuatan video promosi dengan menggunakan teknik motion grafis. Perancangan motion grafis ini agar terlihat lebih menarik dan dapat mengajak masyarakat di Indonesia untuk menyalurkan bakat mereka melalui Rockradiolive.co dan juga melestarikan musik rock di Indonesia khususnya untuk wilayah Jabodetabek. Tujuan perancangan video promosi ini adalah untuk mengajak band rock dan metal untuk menyebarluaskan karyanya melalui Rockradiolive.co. Serta menciptakan sudut pandang masyarakat terhadap Rockradiolive.co sebagai sarana untuk menyebarluaskan karya musik band rock baru.

7. Penelitian yang dilakukan oleh Vikri Septian (2014) ${ }^{[13]}$, Penelitian yang dilakukan oleh Vikri Septian dengan judul "Perancangan Video Company Profile Pada Rsia Murni Asih Sebagai Media Promosi”. Media informasi berbentuk video merupakan sarana penting sebagai penunjang informasi dan sangat mungkin dirancang untuk pembuatan media company profile, selain sebagai penunjang informasi mengenai sejarah, kualitas, mutu serta kelebihan dan lainnya, media company profile juga bisa disesuaikan dengan tujuan serta demi kelancaran dan efektifitas penyampaian informasi seputar kesehatan sudah saatnya memiliki media informasi dalam bentuk video profile yang menarik dengan visual atau gambar-gambar yang memperjelas sebuah informasi.

8. Penelitian yang dilakukan oleh Dwi Fitri Parmania $(2014)^{[10]}$,dengan judul "Perancangan Video Company Profile Sebagai Media Penunjang Informasi Dan Promosi Pada Pt. Telkom Akses Jakarta”. Penelitian tersebut menjelaskan tentang struktur lembaga telekomunikasi dan jaringan internet di berbagai seluruh Indonesia dan macam-macam tipe dan jenis jaringan maupun koneksi yang di kemas untuk diinformasikan kepada masyarakat luas.

\section{LANDASAN TEORI}

\section{Definisi Pengembangan}

Pengembangan adalah proses peningkatan keterampilan teknis, teoritis, konsepsual dan moral melalui pendidikan dan penelitian. Pendidikan dan penelitian yang diberikan harus sesuai dengan kebutuhan masa kini maupun masa depan ${ }^{[5]}$.

Pengembangan adalah kegiatan - kegiatan pengembangan diri yang ditempuh oleh seseorang untuk mewujudkan rencana pribadinya ${ }^{[8]}$.

Vol.2 No.2 - Agustus 2016 


\section{Pengertian Media}

Media adalah segala bentuk yang digunakan untuk menyalurkan informasi. Pengertian media yang diberikan AECT (Association for education communication and tecnology) ini menunjukkan bahwa istilah "media" memiliki makna yang sangat umum ${ }^{[3]}$.

Media adalah sarana untuk menyimpan pesan atau informasi kepada public dengan menggunakan berbagai unsur komunikasi grafis seperti teks atau gambar atau foto ${ }^{[7]}$.

\section{Pengertian Promosi}

Promosi adalah tindakan menginformasikan atau meningkatkan konsumen tentang spesifikasi produk atau merek. Promosi mempunyai kekuatan untuk menyampaikan pesan, dan diperlukan perancangan khusus agar promosi tersebut memiliki visual yang kuat dan menciptakan keserasian didalam rangkaian pemasaran, karena promosi adalah berkaitan langsung dalam upaya untuk memperkenalkan produk kepada konsumen dengan memikat hati mereka melalui pemberian kesan - kesan baik, yang mampu diingat dan dirasakan oleh konsumen $^{[4]}$.

Promosi adalah suatu bentuk komunikasi pemasaran. Yang dimaksud dengan komunikasi pemasaran adalah aktivitas pemasaran yang berusaha menyebarkan informasi, mempengaruhi atau membujuk dan mengingatkan pasar sasaran atas perusahaan dan produknya agar bersedia menerima dan loyal pada produk yang ditawarkan perusahaan yang bersangkutan ${ }^{[6]}$.

\section{Pengertian Video Digital}

Video digital sebenarnya terdiri atas serangkaian gambar digital yang ditampilkan dengan cepat pada kecepatan yang konstan. Dalam konteks video, gambar ini disebut frame. Satuan ukuran untuk menghitung frame rata-rata yang ditampilkan disebut frame per second (FPS). Setiap frame merupakan gambar digital yang terdiri dari raster pixel ${ }^{[3]}$.

\section{Dinas Porparekraf}

Dinas Porparekraf Kota Tangerang merupakan Dinas yang mempunyai wewenang untuk mempromosikan aset wisata Kota Tangerang. Adapun Dinas tersebut terletak di Gedung Cisadane Lt.II yang beralamatkan di Jl. KS. Tubun No. I Kota Tangerang. Dinas ini dipimpin oleh seorang Kepala Dinas, serta terdapat satu Sekretariat dan tiga bidang, diantaranya : Bidang Kepemudaan, Bidang Olahraga, dan Bidang Pariwisata dan Ekonomi Kreatif.

Saat ini Dinas Porparekraf secara berkelanjutan menata dan mempromosikan aset pariwisata Kota Tangerang sebagai bagian dari upaya meningkatkan kesejahteraan warga Kota Tangerang dan meningkatkan peran Kota Tangerang dalam konsentrasi kepariwisataan nasional. Terbukti dengan adanya video pariwisata Kota Tangerang sebelumnya, namun seiring berkembangnya informasi mengenai Pariwisata yang ada di Kota Tangerang, Dinas Porparekraf membutuhkan video yang baru dengan informasi yang up to date sesuai perkembangan Kota Tangerang saat ini, agar melalui pengembangan video pariwisata ini masyarakat atau wisatawan lebih mengenal obyek-obyek pariwisata yang ada di Kota Tangerang.

\section{METODOLOGI PENELITIAN}

Metode penelitian yang digunakan untuk Pengembangan Media Promosi Pariwisata Kota Tangerang yaitu sebagai berikut : 
(1) Metode Analisa Permasalahan yang didapatkan dengan hasil interview melalui Stakeholder pada Dinas Porparekraf Kota Tangerang.

(2) Metode Pengumpulan Data yang dilakukan dengan cara observasi, interview serta studi pustaka.

(3) Metode Analisa Perancangan Media.

Media video promosi pariwisata yang dibutuhkan oleh Dinas Porparekraf Kota Tangerang akan diproduksi menggunakan software editing yaitu sebagai berikut :

(1) Addobe Premiere CC

(2) Adobe After Effect CC

(3) Adobe Illustrator CC

(4) Metode Konsep Produksi Media (KPM).

\section{PEMBAHASAN}

Merancang sebuah media audio visual khusus nya video peromosi pariwisata Kota Tangerang, perlu melakukan beberapa tahapan dalam konsep produksi Media (KPM), adapun tahapan yang perlu dilakukan yakni preproduction, production, dan postproduction.

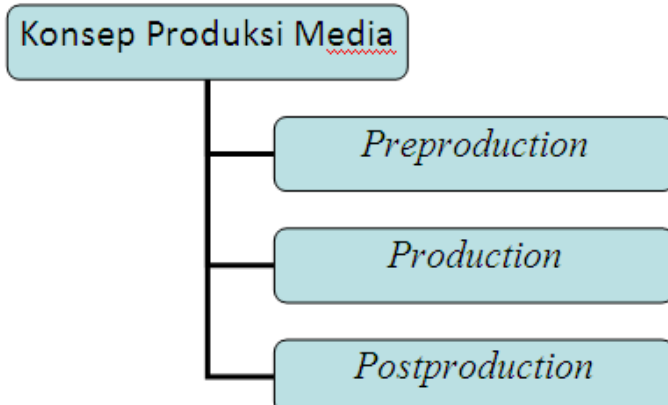

Gambar 1.Bagan Konsep Produksi Media

\section{Preproduction}

Ada beberapa tahapan preproduction dalam pembuatan Video Promosi Pariwisata Kota Tangerang, diawali dengan observasi lapangan dan mengumpulkan data-data yang dibutuhkan, setelah itu dituangkan dalam sebuah ide atau gagasan secara sistemastis, supaya dapat menghasilkan video dengan baik. Dalam penelitian ini media informasi yang digunakan yaitu video digital dengan konsep video mengexplore destinasi wisata Kota Tangerang dengan menggunakan teknik video cinematic yang saat ini sedang menjadi tren.

Video promosi pariwisata yang menarik ditunjukan kepada masyarakat Kota Tangerang, yang di lengkapi dengan pembuatan sinopsis, script writting serta storyboard. Ada 2 (dua) tahapan yang terakhir yaitu pemilihan dubbing. Semua tahapan harus sesuai dengan time schedule yang diterapkan.

Untuk lebih jelasnya, maka dapat diilustrasikan pada bagan berikut ini : 


\section{PREPRODUCTION}

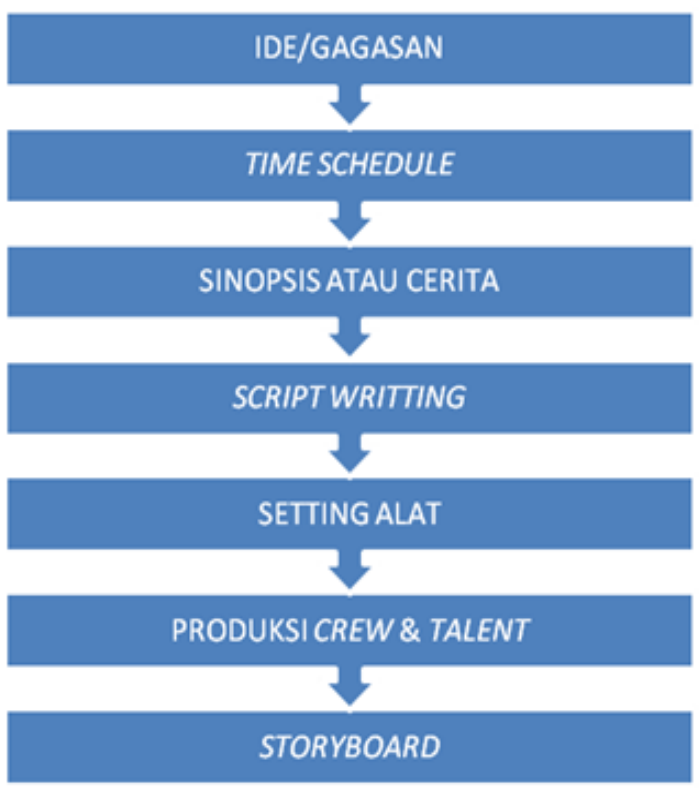

Gambar 2. Preproduction

\section{Observasi}

Pengamatan yang telah dilakukan kepaada Dinas Porparekraf Kota Tangerang, mengenai sudah atau tidak adanya video promosi pariwisata, dalam setiap promosi yang dirancang oleh Kota Tangerang.

\section{Ide}

Dinas Porparekraf Kota Tangerang ingin meningkatkan promosi mengenai Pariwisata Kota Tangerang yang terbaru. Media video promosi salah satu media yang sangat efektif untuk menyampaikan informasi dan promosi tentang pariwisata Kota Tangerang, sehingga bisa menarik, memudahkan masyarakat dan wisatawan yang ingin mengetahui tentang destinasi pariwisata yang ada di Kota Tangerang dan dapat menunjang efektifitas dalam proses komunikasi.

\section{Pemecahan Masalah}

1. Untuk menyajikan sebuah video pariwisata Kota Tangerang yang informatif, oleh karna itu dibutuhkan pengembangan video promosi pariwisata dengan informasi yang up to date sesuai dengan perkembangan pariwisata Kota Tangerang saat ini, karena media audio visual menampilkan rangkaian berupa gambar, video, dan musik, yang digunakan untuk keperluan seperti untuk memperkenalkan, menginformasikan dan mempromosikan Kota Tangerang yang memiliki sejarah panjang dan menyimpan beragam potensi pariwisata, baik wisata alam, wisata religi, wisata budaya, maupun wisata kuliner, yang menarik untuk menjadi tujuan destinasi wisata, guna menunjang promosi pariwisata Kota Tangerang.

Vol.2 No.2 - Agustus 2016 
2. Dalam membuat media audio visual yang berkonsep menarik dan dapat memenuhi kebutuhan promosi Kota Tangerang maka dibutuhkan kualitas video yang baik seperti tampilan yang beresolusi tinggi dan sajian video yang menampilkan banyak pilihan gambar, dengan menyatukan berbagai effect visual, gambar, dan suara yang dikemas kedalam video promosi dan ditampilkan dalam durasi yang tidak terlalu panjang, agar lebih efektif dan tepat sasaran video ini di implementasikan melalui $D V D$ dan berbagai media sosial seperti Youtube, Website Kota Tangerang, Website Dinas Porparekraf dan Tangerang TV.

3. Target yang diharapkan Dinas Porparekraf melalui pengembangan video pariwisata Kota Tangerang yaitu agar Dinas Porparekraf mencapai target promosi yang diharapkan yaitu meningkat sebanyak 35\% masyarakat atau wisatawan, untuk lebih mengenal obyek-obyek pariwisata yang ada di Kota Tangerang dan dapat menarik wisatawan dan investor lokal dan dapat meningkatkan sumber pendapatan daerah, sehingga Kota Tangerang menjadi live city, yaitu Kota yang layak di tempati, layak investasi, layak dikunjungi dan E-city (Smart City).

\section{Sinopsis / Cerita}

Sinopsis/cerita merupakan konsep cerita yang akan dibuat atau mencerminkan alur cerita dari awal sampai akhir adegan. Sinopsis pengembangan media promosi pariwisata kota Tangerang dalam bentuk video digital pada Dinas Porparekraf ini adalah:

"Kota Akhlakul Karimah, itulah julukan yang kini melekat pada Kota Tangerang. Sebuah Kota Metropolitan yang tumbuh dan berkembang pesat dibandingkan dua dekade lalu. Kota yang banyak melakukan terobosan dalam berbagai bidang dan meraih berbagai prestasi tingkat provinsi, Nasional, bahkan internasional. Kota Tangerang sedang bergerak menjadi Live City. Yaitu kota yang layak ditempati, layak investasi, layak dikunjungi dan e-city (Smart City). Kota Tangerang layak dijadikan tujuan pilihan pariwisata, Sebagaimana di ketahui sektor pariwisata memiliki potensi besar untuk memberikan kontribusi signifikan bagi pertumbuhan daerah dan mewujudkan cita-cita kota yang layak dikunjungi. Kota yang memiliki destinasi wisata yang menarik ini dibagi menjadi beberapa destinasi pariwisata yaitu, wisata alam, wisata religi, wisata sejarah dan budaya, wisata kuliner dan wisata belanja. Hj. R. Rina Hernaningsih, SH. MH. selaku Kepala Dinas Porparekraf mempunyai ambisi untuk mengembangkan dan mempromosikan destinasi pariwisata Kota Tangerang sebagai salah satu kota yang memiliki potensi pariwisata yang strategis. Oleh karena itu dibutuhkan pengembangan video promosi pariwisata Kota Tangerang yang selalu diperbarui setiap tahunnya."

\section{Storyboard}

Storyboard merupakan sebuah gambar sket yang dilengkapi dengan petunjuk ataupun cacatan pengambilan gambar pada sebuah video untuk kebutuhan pembuatan film. Selama proses production berlangsung pengembangan yang berhubungan dengan video promosi pariwisata yang akan dibuat membutuhkan storyboard sebagai media pembantu. Adapun storyboard dalam video promosi pariwisata Kota Tangerang pada Dinas Porparekraf adalah sebagai berikut :

Vol.2 No.2 - Agustus 2016 


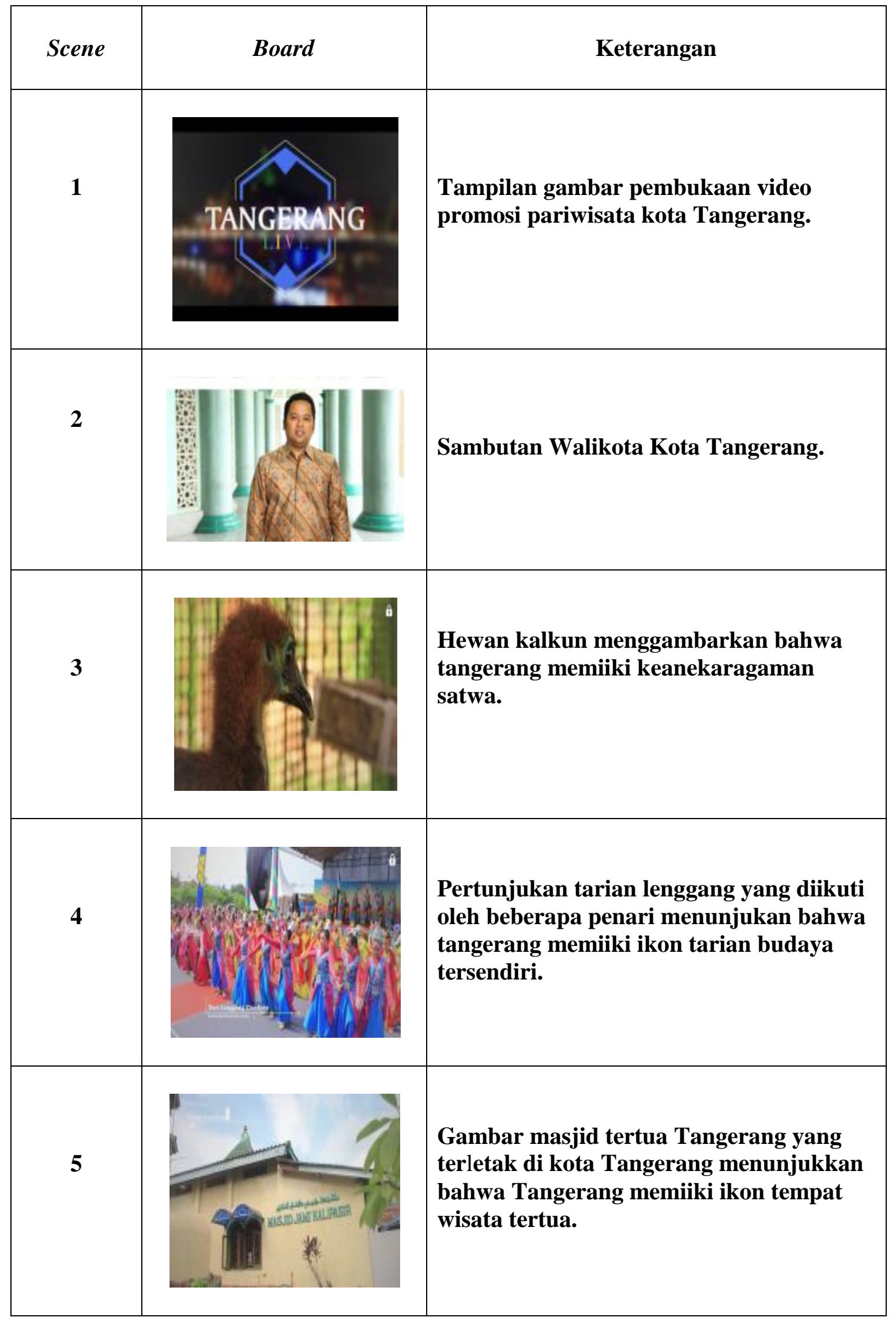

Vol.2 No.2 - Agustus 2016 


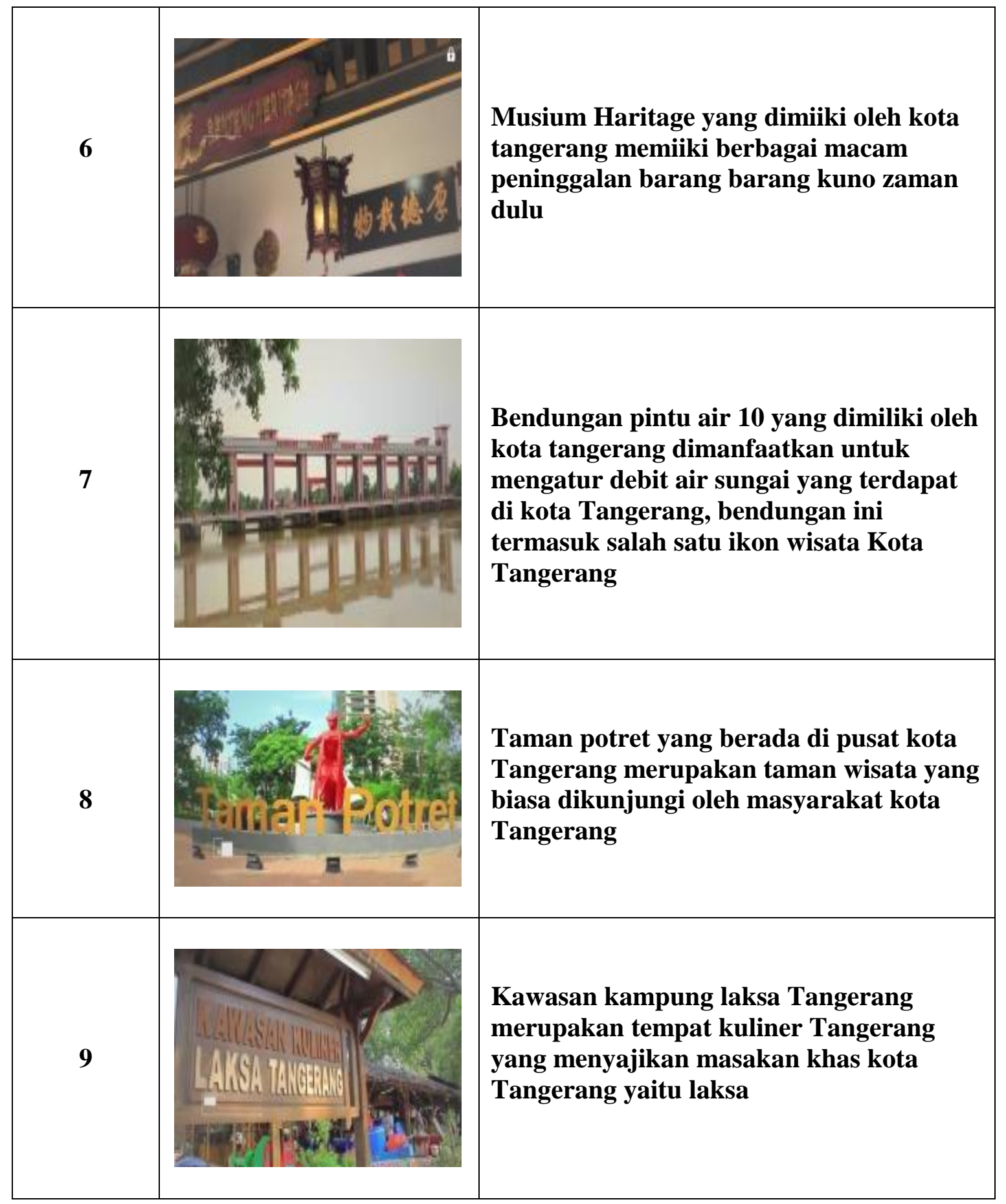

\section{Setting Alat}

Dalam setiap proses pembuatan video selalu dibutuhkan alat bantu untuk membuat video diantaranya yaitu : Camera, Tripod, Lighting serta Mic Camera. Selain itu camera yang digunakan untuk memproduksi video promosi pariwisata Kota Tangerang adalah camera Canon 5D Mark II, Canon 60D Kit II dan Drone Camera.

Adapun equipment camera yang digunakan adalah Tripod, Slider, Mic Recorder, Mini Crane Camera dan SteadyCam.

Vol.2 No.2 - Agustus 2016 


\section{Production}

Tahapan Production adalah proses pengambilan gambar atau biasa disebut dengan shooting. Dalam proses ini dibagi menjadi beberapa tahapan yaitu :

a. Perencanaan multi media yang diperlukan ada tiga tahapan element sistematis antaralain teks, gambar, serta suara. Kemudian di kombinasikan menjadi suatu file yang berbentuk video. Perencanaan multimedia didasarkan dengan konsep yang efektif agar menjangkau masyarakat untuk memperoleh informasi secara efisien dan akurat.

b. Perencanaan audio berperan sangat penting untuk penyampaian informasi dalam bentuk suara. Jika tidak ada audio video yang diputar kurang memuaskan. Karena jika tidak ada audio, langkah yang ditempuh yaitu dengan memperbanyak teks.

c. Perencanaan visual yang dihasilkan yaitu keseluruhan dari penggabungan gambar, teks, dan suara yang menghasilkan suatu video yang utuh untuk digunakan memberikan informasi. Dengan menggabungkan teks dan format penulisan yang sudah di tentukan, gambar yang sudah di produksi sebelum nya dan suara yang dikeluarkan dari hasil membaca naskah kemudian di edit dan di export lalu mendapatkan video yang siap untuk dipergunakan.

d. Perencanaan Broadcasting difungsi- kan untuk menjangkau masyarakat dengan program pendistribusian efisien dan efektif. Dibuatnya perencanaan Broadcasting bertujuan untuk mencakup ruang lingkup masyarakat luas ataupun wisatawan dengan memberikan informasi tentang pariwisata yang ada di Kota tangerang. Dengan dibuatnya perencanaan broadcasting suatu media promosi ataupun informasi menjadi arahan agardapat mencapai target.

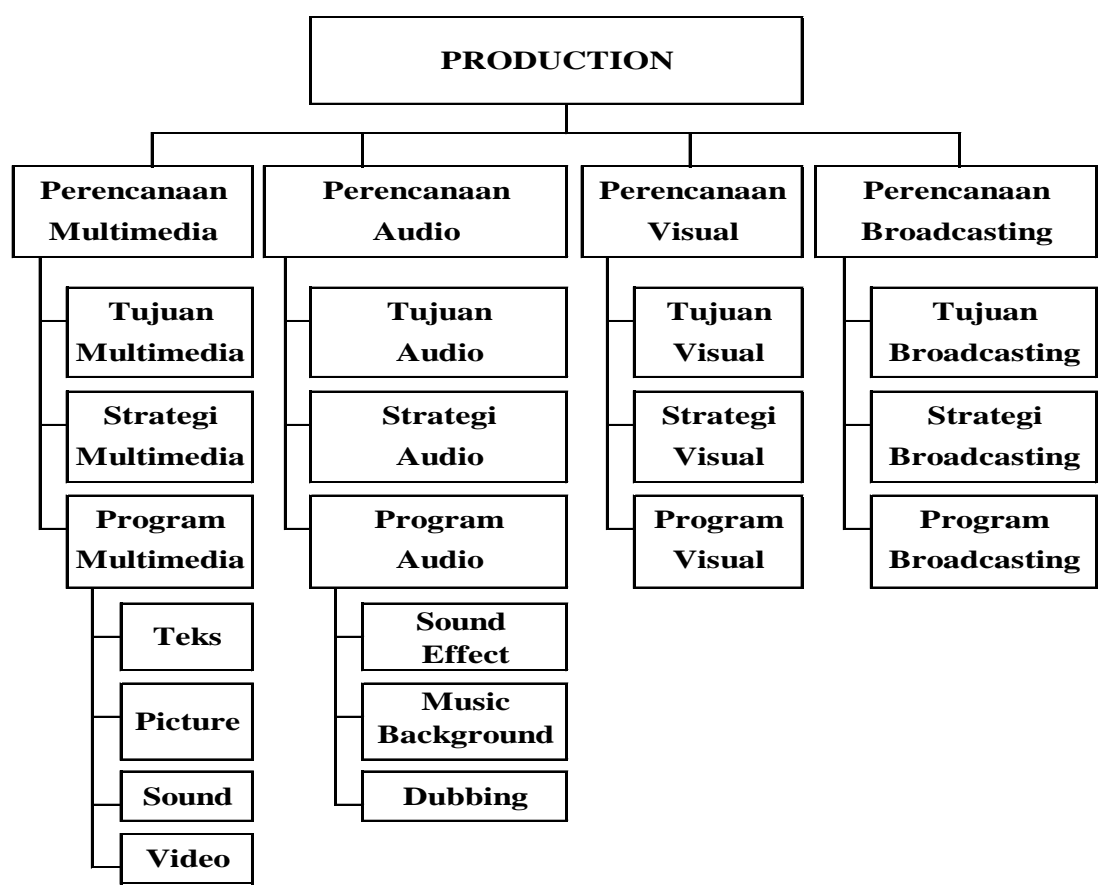

Gambar 7. Bagan Production

Vol.2 No.2 - Agustus 2016 


\section{Postproduction}

Postproduction merupakan taha- pan terakhir Konsep Produksi Media (KPM). Postproduction adalah Proses finishing suatu karya sampai menjadi suatu video yang mampu menyampaikan sebuah informasi.

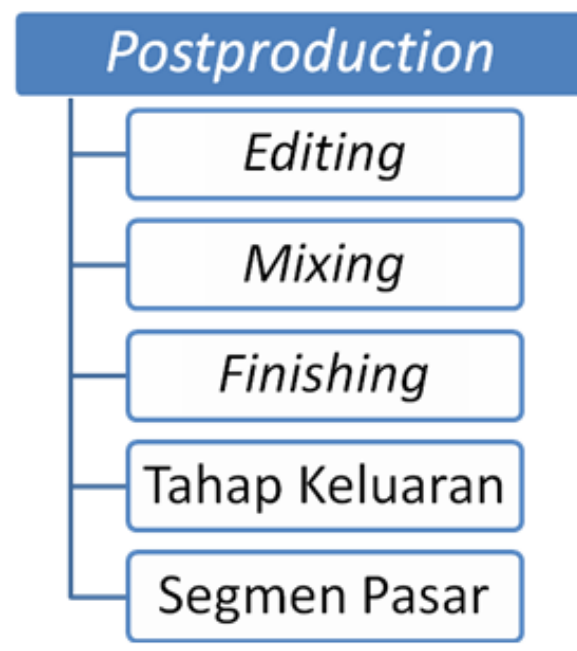

Gambar 8. Bagan Postproduction

\section{KESIMPULAN}

Berdasarkan hasil penelitian jurnal yang telah dilakukan, maka dapat ditarik kesimpulan sebagai berikut :

Untuk menyajikan sebuah video pariwisata Kota Tangerang yang informatif, maka dibutuhkan pengembangan video promosi pariwisata dengan informasi yang up to date sesuai dengan perkembangan pariwisata Kota Tangerang saat ini, dikarenakan media audio visual menyampaikan rangkaian berupa gambar, teks, video, dan musik yang berfungsi untuk keperluan seperti menginformasikan , memperkenalkan dan mempromosikan Kota Tangerang yang sudah memiliki sejarah panjang dan menyimpan keanekaragaman destinasi pariwisata, baik wisata alam, wisata budaya, wisata kuliner, maupun wisata religi yang menarik untuk menjadi tujuan destinasi wisata, untuk menunjang promosi pariwisata Kota Tangerang yang lebih baik.

\section{DAFTAR PUSTAKA}

[1] Akbarian, Mirzza Al. 2012. Perancangan Video Promosi Wisata Jawa Timur. Jawa Timur.

[2] Cristianti, Siti Sofri Ayu. 2015. Perancangan Video Promosi Rockradiolive.Co. Jakarta.

[3] Desrianti, Dewi Immaniar. Untung Rahardja. Reni Mulyani. 2012. Audio Visual As One Of The Teaching Resources On Ilearning. Journal CCIT Vol. 5 No. 2. Tangerang : Raharja

Vol.2 No.2 - Agustus 2016 
[4] Destrianti, Dewi Immaniar, Sudaryono, Dwi Ayu Ningrum. 2014. Enriching Media Merchandise Sarana Penunjang Promosi Studi Kasus Pada Bookstore. Journal CCIT Vol. 7 No.3 - Mei 2014. Tangerang : Perguruan Tinggi Raharja

[5] Hasibuan, Malayu, 2012. Manajemen Sumberdaya Manusia. Edisi Revisi. Cetakan Kelima. Jakarta : Bumi Aksara.

[6] Lukiati, Komala. 2010. Panduan Mudah Merancang Bangunan. Jakarta : Niaga Swadaya.

[7] Maimunah, Lusyani Sunarya, Nina Larasati. 2012. Media Company Profile Sebagai Sarana Penunjang Informasi Dan Promosi. Journal CCIT Vol. 5 No. 3. Tangerang : Raharja.

[8] Marwansyah, 2012. Manajemen Sumber Daya Manusia. Bandung: Alfabeta Meldona, 2009. Malang : Uinmalang Press.

[9] Nasiti, Tyas Ajeng. 2013. Perancangan Video Promosi Surabaya Berupa Tvc Sebagai Media Promosi Kota Surabaya Dengan Mengangkat Pencitraan Sparkling Surabaya. Surabaya.

[10] Parmania, Dwi Fitri. 2014. Perancangan Video Company Profile Sebagai Media Penunjang Informasi Dan Promosi Pada Pt. Telkom Akses Jakarta. Jakarta.

[11] Permana, Yasa Sidik. 2012. Perancangan Dan Pembuatan Video Promosi Wisata Alam Dan Edukasi Lingkungan Dolandeso Boro Daerah Banjar Asri Kabupaten Kulon Progo. Yogyakarta : Kabupaten Kulon Progo.

[12] Santoso, Ahmad. 2015. Perancangan Video Promosi Infografis Destinasi Wisata Kota Surakarta. Surakarta.

[13] Septian, Vikri. 2014. Perancangan Video Company Profile Pada Rsia Murni Asih Sebagai Media. Tangerang.

[14] Setyowati. 2012. Perancangan Video Sebagai Sarana Promosi Daya Tarik Wisata Kabupaten Pasuruan. Pasuruan. 